For those not so fortunate as to be in a teaching situation, the cases make good, intellectually stimulating fireside reading, particularly among a small group of colleagues, for good conversation on how we would handle that particular problem. Or, as would probably often be the case, how we did handle that problem-and what we found out later was wrong with that solution.LeRoy Charles Merrit, University of California, Berkeley.

\section{Library History}

An American Library History Reader; Contributions to Library Literature. Selected by John David Marshall. Hamden, Connecticut: Shoe String Press, 1961. 464p. $\$ 9.00$.

If the rate of publication is any bellwether, interest in American library history is increasing. Within the past year have appeared two monographs on the history of library education, a biography of a public librarian, and two collections of readings. (Sarah K. Vann's Training for Librarianship before 1923; Education for Librarianship Prior to the Publication of Williamson's Report on Training for Library Service, Carl Milton White's The Origins of the American Library School, Martha Boaz's Fervent and Full of Gifts; the Life of Althea Warren, Thelma Eaton's Contributions to American Library History, and the book under review.) For an area in which few people have heretofore shown much interest, these publications are a genuine act of faith.

John David Marshall, acquisitions librarian at the University of Georgia, has edited a collection of papers read before the American Library History Round Table, plus various other articles especially appealing to him, because "I think they merit the preservation a book-and only a book-can give them." Of the papers included in this volume all except three were read before the round table and all except one have been published previously in a variety of library periodicals.

Marshall's anthology is divided into four sections. The two introductory essays are "The Importance of Library History," by Louis Shores, a founder of the round table, and "Long Life to the Library History Round
Table," by Stanley Pargellis, read before the first and second meetings of the organization. Part two contains eleven "historical essays" of varying length and depth of treatment, including personal reminiscences as well as as documented historical papers. Marshall's definition of "historical" is fairly broad; some of the essays are merely records. Biographical essays, some twenty-one in all, comprise the third section, many of them personal reminiscences of the "great librarians" by those who knew them. Part four is a reprinting of the short and sometimes inadequate sketches of the forty librarians chosen for "A Library Hall of Fame" in connection with the seventy-fifth anniversary celebration of the ALA.

As would naturally be true of any collection of papers read before an informal organization such as the ALHRT, the essays in this anthology are uneven in quality. They range from the excellent and thorough esays of Edwin Wolf II, "Franklin and His Friends Choose Their Books," and Clifford K. Shipton's, "John Langdon Sibley, Librarian," to Lawrence Clark Powell's account of the purloining of the Bay Psalm Book at UCLA, "Stop Thief." What particular contribution the latter article makes to American library history would be difficult to discover, but it was read before the ALHRT in June 1953.

If criticism can be made (and it can) that first-rate historical essays in this anthology are rare, it should also be stated that some of the reminiscences, the stuff from which history may later be written, are superb. The reviewer was particularly impressed with the two papers of Marian C. Manley, "Personalities Behind the Development of PAIS" and "A Worm's-Eye View of Library Leaders." Some of the reminiscences reveal the authors' keen insight and achieve a discriminating balance between tribute and fact. Particularly useful are the sketches of less wellknown librarians such as Electra Collins Doren, Frank Avery Hutchins, and Mary Frances Isom. On a par with the Wolf and Shipton essays are Peter Thomas Conmy's on James Louis Gillis and David Mearns' on Herbert Putnam. On the other hand some reminiscences of major figures are poorer than they ought to be, and I cite only the generalizations of Carl Vitz on William $\mathrm{H}$. Brett as an example. 
In his "Long Life to the Library History Round Table," Pargellis suggested specific areas in which the round table might work: the lives and achievements of great librarians, with the idea of isolating a professional ethic; the historical development of particular libraries, and the history of libraries as it is related to the whole of intellectual history. One can scarcely imagine a better guideline than Pargellis gave, and yet one can hardly say that these essays represent complete fulfillment of the basic objectives. Perhaps the chief difficulty is that many librarians have not been trained to write good history.

At $\$ 9.00$ an anthology of American library history ought to include the best writing on that topic. In his introduction Marshall comments: "The anthologist . . . always becomes vulnerable to a slightly unfair kind of criticism; criticism for what he left out as well as for what he put in." Perhaps so, but if these essays warrant presentation in a book-"and only a book"-especially at this price, they ought to fulfill some useful function; and the anthologist should accept some criticism for the exclusions as well as the inclusions.

Particularly disturbing to this reviewer was the failure to include three major works of special value to those who are interested in library history. Jesse $H$. Shera's "The Literature of American Library History" (Library Quarterly, XV (1945), 1-22) might well have been the capstone of Marshall's anthology; and in my opinion no anthology of American library history would be complete without it. Another Shera article, "On the Value of Library History" (Library Quarterly, XXII (1952), 240-251) could properly accompany Shores's and Pargellis' essays in the introductory section. Exclusion of the third item, Verner W. Clapp and Edythe W. First's "ALA Member No. 13: A First Glance at John Edmands" (Library Quarterly, XXVI (1956), 1-22) is inexplicable in view of the heavy biographical bias of the book. In fact, the Clapp and First article could serve as a model for those who want to try their hand at a biographical portrait of one of the "greats." Some of the poorer reminiscences and the "Library Hall of Fame" might have been left out to provide space for these three items.

Does Marshall's book have value? Yes, some of essays are worth having in book form, especially those on the less well known librarians. Perhaps, as the foreword suggests, the volume will also serve to stimulate the writing and publication of other works in library history. What the profession now needs is not another collection of readings but a solid monograph on American library history, preferably $200-250$ pages long, which will give the overview from which further intensive effort may come. The author of such a history may make use of the data from these papers, but will have to go beyond them. Such is the state of the art that any prospective author is still going to have to do most of his own spadework.-Edward G. Holley, University of Illinois.

\section{Publishers on Publishing}

Publishers on Publishing. Selected and edited, with Commentary and an Introduction by Gerald Gross. Preface by Frederic G. Melcher. New York: R. R. Bowker Company and Grosset \& Dunlap, 1961. 491 p. $\$ 5.00$ (cloth), $\$ 2.95$ (paper, Grosset Universal Library).

The wonder grows as one reads these discursive, idiosyncratic, and seldom contradictory remarks on "an occupation for gentlemen" that books ever manage to get published. (That they have some difficulties getting distributed is a pressing problem only tangentially worried at here.) Fredric Warburg's comment on Sir Stanley Unwin's publisher's bible, The Truth About Publishing, candidly acknowledges, "My only criticism of this excellent book is that it tends to asassume that publishing is a rational process."

The reader is impressed by the almost evangelical high-mindedness of publishers; and those who disclaim pretensions to high purpose cheerfully admit they are in the game for the fun of it. Uniformly they protest that only a fool would hope to make a fortune at so hazardous a pursuit. While insisting that any good publisher would have become a millionaire in another field, none would exchange the gain for the fun. This leitmotif takes on the tone of elegy for the reader tracing the growth of publishing from 